\title{
TABLE OF CONTENTS 1
}

Foreword/Joseph Seckbach and Maud Walsh............ ix

Introduction/A Roadmap to Fata Morgana Wladyslaw Altermann . . . XV

List of Authors and Their Addresses ............... xxix

\section{GEOLOGY \\ PART 1: \\ FOSSILS AND FOSSILIZATION}

Nanosims Opens a New Window for Deciphering Organic Matter in Terrestrial and Extraterrestrial Samples

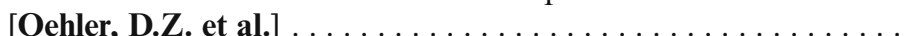

Disentangling the Microbial Fossil Record in the Barberton

Greenstone Belt: A Cautionary Tale [Walsh, M.M.

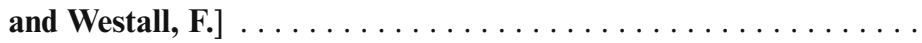

Looking Through Windows onto the Earliest History of Life

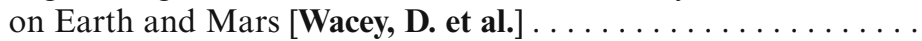

Models for Silicate Fossils of Organic Materials in the

Astrobiological Context [Kolb, V.M. and Liesch, P.J.] . . . . . . . .

Microfossil Phosphatization and Its Astrobiological

Implications [Shuhai Xiao and Schiffbauer, J.D.]

Proterozoic Unicellular and Multicellular Fossils from

India and Their Implications [Tewari, V.C.] . . . . . . . . .

\section{PART 2:}

\section{STROMATOLITES, MICROBIAL MATS, AND BIOFILMS}

Microbial Communities of Stromatolites [Brendan, B.P. et al.] . . . . . .

Biosedimentological Processes That Produce Hot Spring Sinter

Biofabrics: Examples from the Uzon Caldera, Kamchatka

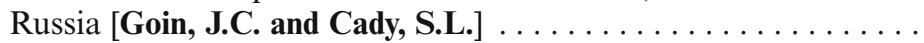

Cyanobacterial Mat Features Preserved in the Siliciclastic

Sedimentary Record: Paleodeserts and Modern Supratidal

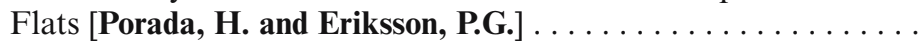

\footnotetext{
${ }^{1}$ The editors thank Professor Julian Chela-Flores for his suggestions for sections and chapter arrangements.
} 
Deciphering Fossil Evidence for the Origin of Life and the Origin of Animals: Common Challenges in Different Worlds

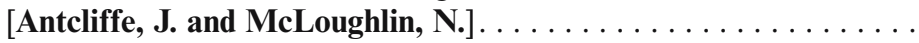

\section{BIOLOGY \\ PART 3: \\ TERRESTRIAL MICROBES AS ANALOGS FOR LIFE ELSEWHERE IN THE UNIVERSE}

Microorganisms in the Ancient Terrestrial Subsurface - And in

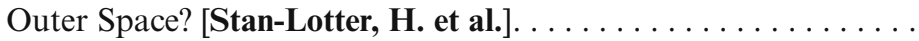

Evidence of Ancient Microbial Life in an Impact Structure

and Its Implications for Astrobiology:

A Case Study [Hode, T. et al.] . . . . . . . . . . . . . . .

Phylogenomic Dating and the Relative Ancestry of Prokaryotic

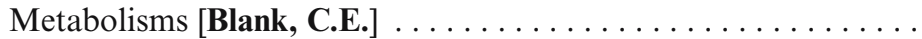

Fossil Microorganisms at Methane Seeps: An Astrobiological

Perspective: Astrobiology of Methane Seeps [Barbieri, R.

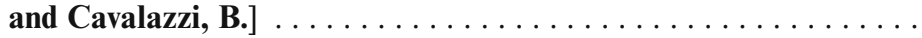

Endoliths in Terrestrial Arid Environments: Implications

for Astrobiology [Stivaletta, N. and Barbieri, R.] . . . . . . . . .

Magnetotactic Bacteria and Their Potential for Terraformation

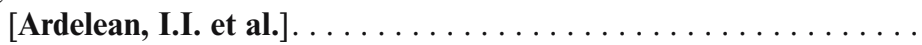

PART 4:

EVOLUTION AND ASTROBIOLOGY

Paleontological Tests: Human-Like Intelligence Is Not

a Convergent Feature of Evolution [Lineweaver, C.H.] . . . . . . 353

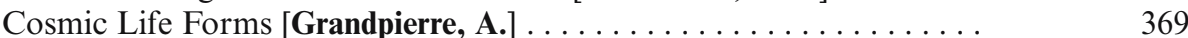

SPACE SCIENCES

PART 5:

ASTRONOMICAL AND COSMOLOGICAL CONSIDERATIONS IN ASTROBIOLOGY

Astronomical and Astrobiological Imprints on the Fossil Records:

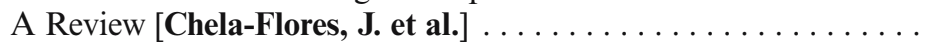

Do Impacts Really Cause Most Mass Extinctions?

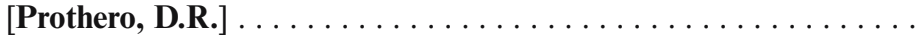

Irradiation of Icy Cometary Analogs: Its Relevance

in Reference to Chemical Evolution and the Origin of Life

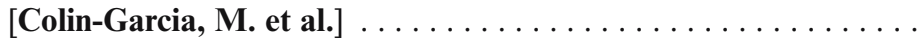


The Big Bang at Time Zero [Bahn, P.R. and Pravdo, S.H.] ........ 443

Molecular Imprints of Reaction Network: Living or Non-living

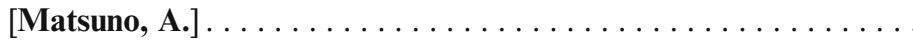

PART 6:

THE SEARCH FOR EVIDENCE OF LIFE ON MARS

The ALH84001 Case for Life on Mars [Davila, A.F. et al.]. . . . . . . . 471

Preservation Windows for Paleobiological Traces in the Mars Geological

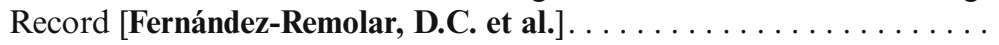

PART 7:

OUTLOOK AND SUMMARY

Summary, Final Comments and Conclusions [Seckbach, J. et al.] . . . .

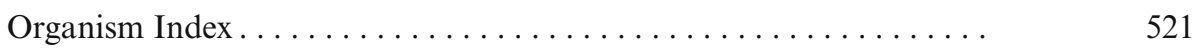

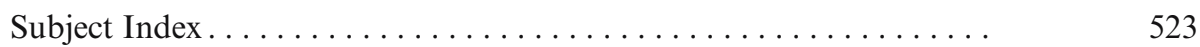

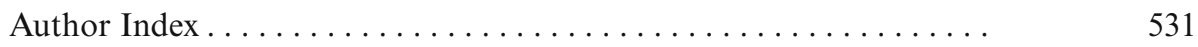

